\title{
Floor of Mouth Squamous Cell Carcinoma
}

National Cancer Institute

\section{Source}

National Cancer Institute. Floor of Mouth Squamous Cell Carcinoma. NCI Thesaurus. Code C4041.

A squamous cell carcinoma of the oral cavity that arises from the floor of the mouth. 